\title{
Observational analysis of Birth, Neonatal Intensive Care Unit and Deaths in Brazil during the first year of the New Corona Virus Pandemic
}

\author{
Análise observacional de Nascimentos, Unidades de Terapia Intensiva Neonatal e Mortes no Brasil \\ durante o primeiro ano da Pandemia do Novo Corona Vírus \\ Análisis observacional de Nacimientos, Unidades de Cuidado Intensivo Neonatal y Muertes en
}

Brasil durante el primer año de la nueva Pandemia del Virus Corona

Received: 07/22/2021 | Reviewed: 07/28/2021 | Accept: 07/30/2021 | Published: 08/05/2021

\author{
Mario Cezar Saffi Junior \\ https://orcid.org/0000-0002-4703-641X \\ Universidade Estadual de Ponta Grossa, Brazil \\ Centro Universitário de Maringá, Brazil \\ E-mail: mariosaffi@gmail.com \\ Luiz Antonio Favero Filho \\ https://orcid.org/0000-0002-8884-9804 \\ Universidade Federal do Espirito Santo, Brazil \\ E-mail: luizfavero@gmail.com \\ Giovani Marino Favero \\ https://orcid.org/0000-0002-1946-3262 \\ Universidade Estadual de Ponta Grossa, Brazil \\ E-mail: gmfavero@uepg.br
}

\begin{abstract}
The Brazilian healthcare structure has evolved in recent decades, but there are still shortages of beds in Intensive Care Units, especially in Neonatal Units. In early December 2019 they reported the first cases of a new infectious coronavirus disease (COVID-19), caused by severe acute respiratory syndrome coronavirus 2 (SARS-CoV-2). The present work makes an observational assessment of the number of deaths in the year 2020 related to the New Coronavirus Pandemic, the number of births and the panorama of Neonatal Intensive Care Unit (NICU) in the last decade. The results showed an increase in the number of deaths, with a predilection for elderly men; reduction in the number of births evaluated by the civil registry and an increase in NICUs in the last decade. This ratio was 2.6 beds per thousand births in 2010, rising to 2.9 per thousand in 2019 and reaching 3.4 beds per thousand births in 2020 . Thus, the forced increase in the number of beds in the therapy unit The intensive care unit approached the proportion recommended by the Brazilian Society of Pediatrics, which is 4 beds for every thousand births.
\end{abstract}

Keywords: Neonatal intensive care unit; Covid-19; Live birth.

\section{Resumo}

A estrutura de saúde brasileira vem evoluindo nas últimas décadas, porém ainda observam-se carências de leitos em Unidades de Terapia Intensiva, em especial as Neonatais. No início de dezembro de 2019 forma relataram os primeiros casos de uma nova doença infecciosa por coronavírus (COVID-19), causada pela síndrome respiratória aguda grave coronavírus 2 (SARS-CoV-2). O presente trabalho faz uma avaliação observacional do número de mortos no ano de 2020 relacionados à Pandemia do Novo Coronavírus, o número de nascimentos e o panorama de UTIs Neonatais na última década. Os resultados mostraram um aumento no número de mortos, com predileção a homens idosos; redução no número de nascimentos avaliados pelo registro civil e um aumento das UTIs Neonatais na última década. Essa relação era de 2,6 leitos para cada mil nascimentos em 2010, passando para 2,9 por mil em 2019 e chegando a 3,4 leitos por mil nascimentos em 2020. Assim, o aumento forçado do número de leitos em unidade de terapia intensiva aproximou a proporção preconizada pela Sociedade Brasileira de Pediatria que é de 4 leitos para cada mil nascimentos.

Palavras-chave: Unidades de terapia intensiva neonatal; Covid-19; Nascido vivo.

\section{Resumen}

La estructura de salud brasileña ha evolucionado en las últimas décadas, pero todavía hay escasez de camas en las Unidades de Cuidados Intensivos, especialmente en las Unidades Neonatales. A principios de diciembre de 2019 informaron los primeros casos de una nueva enfermedad infecciosa por coronavirus (COVID-19), causada por el síndrome respiratorio agudo severo coronavirus 2 (SARS-CoV-2). El presente trabajo realiza una valoración observacional del número de muertes en el año 2020 relacionadas con la Pandemia del Nuevo Coronavirus, el número 
de nacimientos y el panorama de las ITU neonatales en la última década. Los resultados mostraron un aumento en el número de muertes, con predilección por los hombres mayores; reducción del número de nacimientos evaluados por el registro civil y aumento de las UCI neonatales en la última década. Esta relación fue de 2.6 camas por mil nacimientos en 2010, subiendo a 2.9 por mil en 2019 y llegando a 3.4 camas por mil nacimientos en 2020. Así, el aumento forzado en el número de camas en la unidad de terapia La unidad de cuidados intensivos se aproximó a la proporción recomendada. por la Sociedad Brasileña de Pediatría, que es de 4 camas por cada mil nacimientos.

Palabras clave: Unidades de cuidado intensivo neonatal; Covid-19; Nacimiento vivo.

\section{Introduction}

The Brazilian healthcare structure has been evolving in recent decades, the interaction between the public system, the Unified Health System, philanthropic and private hospitals, is the main growth factor in medical care (Machado et al., 2019).

In early December 2019, several local health facilities in Wuhan, China reported the first cases of pneumonia of unknown origin. This new infectious coronavirus disease (COVID-19), caused by the severe acute respiratory syndrome coronavirus 2 (SARS-CoV-2), was primarily identified as an unknown beta-coronavirus (Huang et al., 2020; Zhu et al., 2020).

Since then, studies have increasingly shown that SARS-CoV-2 can be transmitted effectively between humans, and with transmission capacity even before the onset of symptoms (Chan et al., 2020; Li et al., 2020; Rothe et al., 2020). This pandemic has evolved and expanded to dramatic levels around the world, especially with the identification of potentially more transmissible variants reported from the end of 2020 (Vrancken et al., 2021; Sabino et al., 2021). According to the World Health Organization, on March 8, 2021 the world reached a total of 116,363,935 confirmed cases and 2,587,225 deaths (World Health Organization, 2021).

The great challenge of 2020 was to provide a hospital structure to save as many lives as possible (Zangrillo, A.et. al., 2020). The progression of the disease generated by the new coronavirus caused the number of deaths to be increased, and, interestingly, births decreased during the first year of the pandemic (Rocca-Ihenacho, 2020).

The health structure for the hospitalization of newborns who need an intensive care unit is still deficient in the country. The Brazilian Society of Pediatrics recommends four beds for every thousand born, which does not occur in any unit of the federation (SBP, 2018a).

The present work makes an observational assessment of the number of deaths, births and a correlative speculation of ICU beds during the year 2020.

\section{Methodology}

The work makes an observational assessment, with a simple systematic review protocol (Meyerowitz-Katz \& Merone, 2020). Data were collected from primary articles available in scientific databases such as PubMed, MedLine, Medrxiv, Scielo and government publications from 2000 to 2021. Data from the Brazilian Institute of Geography and Statistics, Federal Council of Medicine, were also explored. National Civil Registry Center, Ministry of Health and Brazilian Society of Pediatrics. Initially, a vast mapping of works related directly or indirectly to the subject was carried out, aiming at the combination of empirical and theoretical literature in the direction of identifying the related knowledge gap, reviewing theories and methodological evaluations, in addition to defining concepts based on the data.

Numerical evaluation of the relationship between selected variables such as: death, death by covid-19, births, malformation, Intensive Care Units, Pediatric Intensive Care Units.

Analyzes were transformed into data using a free WPS Office spreadsheet program - Spreadsheets (available at https://www.wps.com/download/). 


\section{Results and Discussion}

The period covering the first death notified by the consequences of covid-19, from March 17th to the last day of the year, is 290 days. During that time, 194,949 deaths related to this pandemic were reported in Brazil. In the whole year, there were $1,450,994$ deaths, that is, $13.4 \%$ of the amount was directly related to this new disease. Figure 1 shows theevolutionof deaths in this period (Registro Civil, 2021).

Figure 1: Curve of deaths during the New Corona Virus Pandemic in 2020. Total of 290 days.

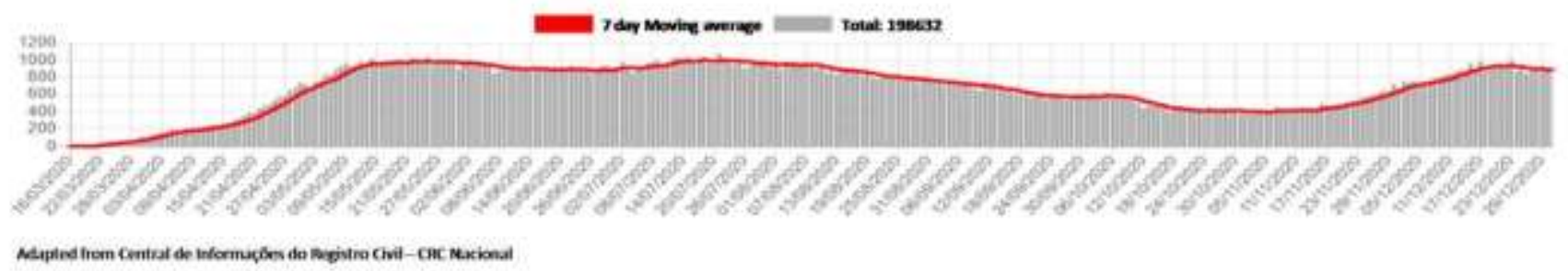

Source: Adapted from Central de Informações do Registro Civil - CRC Nacional.

Figure 1 shows that there was an increase in Pandemic-related deaths in the fall and winter periods, followed by a decline in spring and a slight increase towards the end of the year. In our study, the most important thing was to relate this increase in deaths compared to previous years.

The data found in the registry office shows that, in Brazil, 76\% of the dead were elderly over 60 years of age. Regarding gender $57 \%$ of people who lost their lives were men. Thus, most deaths were among elderly men. This gender division in this period can be seen in Figure 2.

Figure 2: Deaths in the 2020 Pandemic period by age and gender. Note that the highest incidence was related to elderly men.

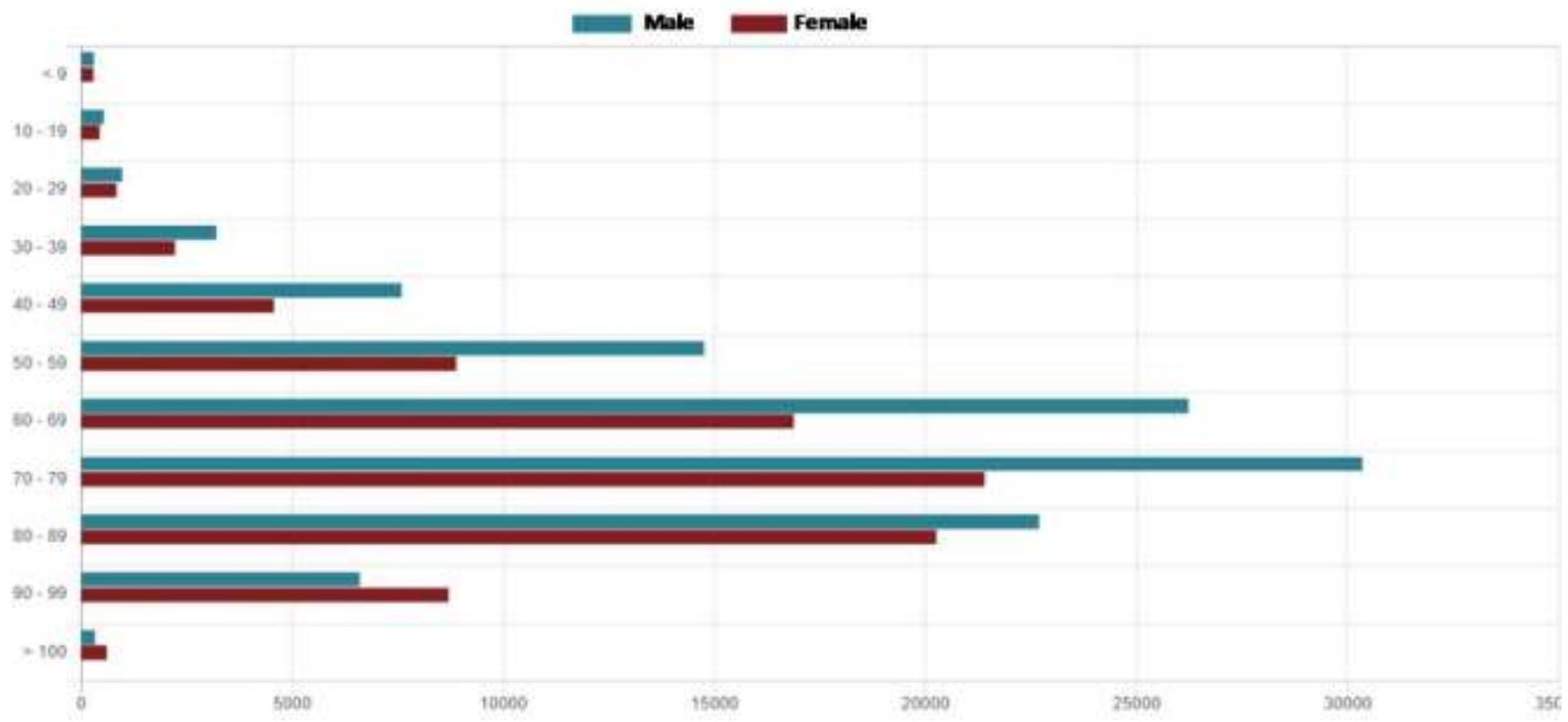

Adapted from Central de informaç̄̈es do Registro Civil-CRC Nacional

Source: Adapted from Central de Informações do Registro Civil - CRC Nacional. 
Elderly people in general were the most affected by covid-19 (Perrotta, F., Corbi, G. et al.,2020). The death of elderly men aged just over sixty, as seen in Figure 2, will directly reflect on the life expectancy of the Brazilian population as a whole.

Compared to the year before the pandemic, 2019, we had 1,262,200 deaths. What is clear is that this $13.1 \%$ increase in the number of deaths is directly related to the new corona virus pandemic (Registro Civil, 2021).

The intense number of deaths with less than life expectancy at birth should, for the first time in over a hundred years, reduce this index. In 2019, the expectation was 75.9 years for Brazilians. The values for 2020 and the projection for 2021 have not yet been calculated.

When addressing the issue of new births, there was an important difference between these two years, 2019 and 2020. The year 2019, pre-pandemic, had a total of 2,774,332 registered births, while the year 2020 had a total of 2,602,960 registered births (Registro Civil, 2021).

Social evaluations indicate that couples rationally postponed the reproductive decision. The economic crisis generated by the pandemic plays an important role in influencing this decision (López-Morales et al., 2021).

This relationship between the increase in the number of deaths compared to previous years and the decrease in births caused the country's growth rate to have a slower pace, leading to a vegetative growth of the population. This period changes the expectation of the Brazilian population plateau in up to a decade and projects a decline in growth for a period before 2040, as projected previously.

According to the Brazilian Society of Pediatrics, based on data from the Ministry of Health, in Brazil we have an average of 900 births of premature babies per day (SBP,2018b). Without taking into account the social and economic differences in different regions of the country, there is a deficit of three thousand beds in Neonatal Intensive Care Units in the country. Figure 3 shows a curve related to births and another related to the number of NICUs with reference to the years 2010, 2018 and 2020 (Registro Civil, 2021). Due to the new coronavirus pandemic, the federal government expanded it to 159 new neonatal intensive care units in the country.

In Brazil, the percentage of stillbirths per year is around 14 per 1000 births and the number of stillbirths is $1.5 \%$ (Victória et al. 2001). Thus, with a decrease in births, we can speculate that the burden on neonatal ICUs was lower, but still deficient based on the proportion indicated by the Brazilian Society of Pediatrics (SBP,2018b). In the year 2020, approximately 80,000 stillbirths occurred in Brazil (Richtmamn et al., 2020). It is noteworthy that in Brazil, congenital malformations constitute about $12 \%$ of the causes of infant mortality (Fontoura et al., 2014). What we can conclude, even with the changed scenario due to the pandemic, is that neonatal mortality, deaths under 28 days, is inversely proportional to the number of beds available.

Figure 3: A) Evolution of the number of Neonatal Intensive Care Units in Brazil, 2010,2018,2020. B) Absolute number of births registered in Brazil in the years 2010, 2018 and 2020. C) Ratio of NICU number per births in Brazil, Ideal is the proportion suggested by the Brazilian Society of Pediatrics.

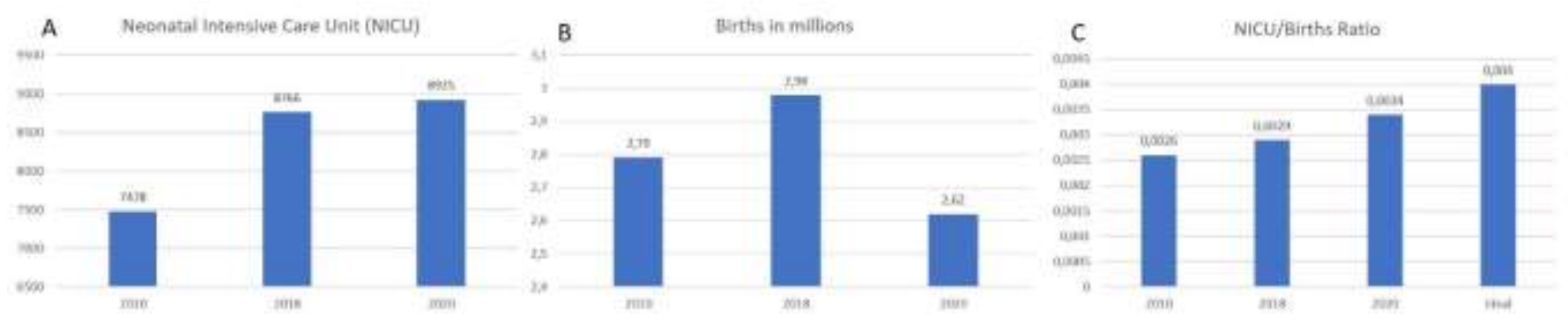

Source: Authors. 
This approximation of the ideal number of beds, as seen in Figure 3, was directly associated with a lower rate of births that should return to grow in the following year, thus the need for new beds in the Neonatal Intensive Care Unit remains necessary.

\section{Conclusion}

The pandemic induced an increase in the number of deaths and, consequently, a decrease in the average life expectancy of Brazilians. On the other hand, the birth rate was lower compared to previous years, causing vegetative growth to occur earlier. Taking into account the growing increase in ICUs in Brazil and, due to the pandemic, an increase in more than one hundred beds for neonatal units. This ratio of units, which was 2.6 beds per thousand births in 2010 , rose to 2.9 per thousand in 2019 and reached 3.4 beds per thousand births in 2020. Thus, the forced increase in the number of beds in intensive care unit approximated the proportion recommended by the Brazilian Society of Pediatrics, which is 4 beds for every thousand births.

This work focused on the first year of the Pandemic, so studies of the following years must be carried out, and a global assessment after the end of this cycle of the New Corona Virus must be made.

\section{References}

Chan, J. F. (2020) A familial cluster of pneumonia associated with the 2019 novel coronavirus indicating person-to-person transmission: a study of a family cluster. Lancet.395(10223):514-523.

Fontoura, F. C., \& Cardoso, M. V. L. M. L. (2021). Association between congenital malformation and neonatal and maternal variables in neonatal units of a Northeast Brazilian city. Texto \& Contexto - Enfermagem [online]. 2014, 23(4), pp. 907-914. <https://doi.org/10.1590/0104-07072014002320013>. Epub Oct-Dec 2014. ISSN 1980-265X. https://doi.org/10.1590/0104-07072014002320013.

Huang, C. (2020). Clinical features of patients infected with 2019 novel coronavirus in Wuhan, China. Lancet; 395(10223):497-506.

López-Morales, H., et al. "Mental health of pregnant women during the COVID-19 pandemic: A longitudinal study.” Psychiatry research vol. 295 (2021): 113567. 10.1016/j.psychres.2020.113567

Li, R. (2020). Substantial undocumented infection facilitates the rapid dissemination of novel coronavirus (SARS-CoV2). Science.

Machado, C. V., Silva, G. A. E. (2019) Political struggles for a universal health system in Brazil: successes and limits in the reduction of inequalities. Global Health. Nov 28;15(Suppl 1):77. 10.1186/s12992-019-0523-5.

Meyerowitz-Katz, G., \& Merone, L. (2020). A systematic review and meta-analysis of published research data on COVID-19 infection fatality rates, International Journal of Infectious Diseases, Volume 101.

Perrotta, F., Corbi, G., Mazzeo, G., et al. (2020). COVID-19 and the elderly: insights into pathogenesis and clinical decision-making. Aging Clin Exp Res 32, 1599-1608. https://doi.org/10.1007/s40520-020-01631-y

Registro Civil. (2021). https://registrocivil.org.br/

Richtmann, R., Torloni, M. R., Otani, A. R. O., Levi, J. E., Tobara, M. C., Silva, C. A., Dias, L., Miglioli-Galvão, L., Silva, P. M., \& Kondo, M. M. Fetal deaths in pregnancies with SARS-CoV-2 infection in Brazil: A case series. (2020). Case Reports in Women's Health, 2020, Volume 27, e00243, ISSN 22149112, https://doi.org/10.1016/j.crwh.2020.e00243.

Rocca-Ihenacho, L., \& Alonso, C. (2020). Where do women birth during a pandemic? Changing perspectives on Safe Motherhood during the COVID-19 pandemic. Journal of Global Health Science, 2(e4), 10.35500/jghs.2020.2.e4

Rothe C. (2020). Transmission of 2019-nCoV infection from an asymptomatic contact in Germany. N Eng1 J Med. $2020 ; 382(10): 970-971$.

Sabino, E. C. (2021). Resurgence of COVID-19 in Manaus, Brazil, despite high seroprevalence. The Lancet. 397(10273):452-455.

SBP (2018a). Faltam 3,3 mil leitos de UTI neonatal no País, denuncia a SBP ao cobrar medidas para o Nascimento Seguro de brasileiros. Website da Sociedade Brasileira de Pediatria. https://www.sbp.com.br/imprensa/detalhe/nid/faltam-33-mil-leitos-de-uti-neonatal-no-pais-denuncia-a-sbp-ao-cobrarmedidas-para-o-nascimento-seguro-de-brasileiros/

SBP (2018b). Levantamento da Sociedade Brasileira de Pediatria revela que Brasil tem déficit de leitos de UTI neonatal. Website da Sociedade Brasileira de Pediatria. https://www.sbp.com.br/imprensa/detalhe/nid/levantamento-da-sociedade-brasileira-de-pediatria-revela-que-brasil-tem-deficit-de-leitos-de-utineonatal/

Victora, C. G., \& Barros, F. C. (2001). Infant mortality due to perinatal causes in Brazil: trends, regional patterns and possible interventions. Sao Paulo Med J. 119: $33-42$ 
Research, Society and Development, v. 10, n. 10, e81101018578, 2021

(CC BY 4.0) | ISSN 2525-3409 | DOI: http://dx.doi.org/10.33448/rsd-v10i10.18578

Vrancken B. (2021). Phylogenetic analyses of SARS-CoV-2 B. 1.1. 7 lineage suggest a single origin followed by multiple exportation events versus convergent evolution. bioRxiv.

World Health Organization (2021). WHO Coronavirus (COVID-19) Dashboard. https://covid19.who.int/

Wu A. (2020). Genome composition and divergence of the novel coronavirus (2019-nCoV) originating in China. Cell Host \& Microbe. 27(3):325-328.

Zangrillo, A., et. al., (2020). Fast reshaping of intensive care unit facilities in a large metropolitan hospital in Milan, Italy: Facing the COVID-19 pandemic emergency. Critical Care and Resuscitation, 22(2), 91-94.

Zhu N. (2020). A novel coronavirus from patients with pneumonia in China, 2019. N Engl J Med.382(8):727-733. 